\title{
磁気歯車伝達系のロバスト制御*
}

\author{
田宏 奇*1, 長 屋 幸 助*1, 井開 重 男*1
}

\section{Robust Control of Magnetic Gear Transmitting System}

\author{
Hongqi TIAN, Kosuke NAGAYA and Shigeo IKAI
}

\begin{abstract}
A new magnetic gear transmitting system with an actuator made of an electromagnet is proposed in this paper. The vibration due to the system parameter variations or external disturbance is absorbed by means of changing magnetic fluxes of the electromagnet and the controller is designed by variable structure system (VSS) theory. The theoretical expressions of the transmitting torque, magnetic spring constant and control force versus electric current in the electromagnet were derived. Both the simulations and experiments of this magnetic gear system were carried out by means of the sliding mode regulator and were compared with the PID linear control method. The experimental results confirmed the theoretical analyses.
\end{abstract}

Key Words: Dynamics of Machinery, Magnetic Gears, Electromagnet, Permanen Magnet, Transmission Torque, Robust Control, Sliding Mode Control

\section{1. 維}

振動制御は急速な発展を遂げており，永久磁石ある いは電磁石を用いたアクティブ制御の研究も盛んであ る(1) (3). 磁気を用いた, 機械要索の一つとして, 近時 吸引形磁気霜車伝達系も鶴本(4)により提案され，長屋 らはその伝達トルクの解析を確立した(5)。磁気菌車は 非接触で摩擦もなく，隔壁を通してトルクを伝達でき るのと歯自体から発生する騷音がないなど，多くの特 長を備えて拉り，今後多方面に利用されていくものと 思われる.しかしこの系では，雪と菌が磁気吸引力て 連結されているのでばね定数は通常の霜車系に比べ 格段に小さく，また強度の非線形性を有する，したが って回転中に振動の発生しやすい機構であり，また非 線形性のために，振動制御に通常の線形理論が適用て きない難点がある。

非線形の適応制御の方法として，スライディングモ ード制御があり，すでに多くの問題に適用されてき た(6) -(9). とくに近年は振動制御にも用いられてい $3^{(10)(11)}$. スライディングモード制御の他の方法と異な る点は，運動中の系の変化に対応できることである。

*原稿受付 平成 4 年 2 月 26 日.

*1 正員, 群馬大学工学部（6376 桐生市天神町 1-5-1).
このことは他の制御法に比べロバスト性があり，とく に非線形制御系の設計を容易にする。

本報は永久磁石より成る磁気歯車系の非線形振動を 電磁石をアクチュエータとしてスライディングモード により制御する方法を提案するものである．その具体 的方法は，電磁石により永久磁石の磁界をコンピュー 夕制御により適切に変化させて制御力を与えるもので ある。本系には強い非線形性があるため, 共振時近く の変位の大きくなった点では従来の線形制御では対応 できないので, 本制御法が有効と考えられる。

解析では，まず，系のばね定数，伝達卜ルクならび に制御力を電磁気学に基づき誘䢘し，数值計算を行っ た。ついで本系の運動方程式を求め，その振動制御の ためにスライディングモードレギュレータを構築し， 実際に実験を行った結果と比較し，本方法の妥当性を 検証した。

\section{2. 磁束密度およひ伝䢖トルクの解析}

\section{$2 \cdot 1$ 磁気菌車の磁束密度の解析本報で提案す} る磁気歯車伝達系を図 1 に示す。磁界制御用の鉄しん の周上に等間隔に歯があり，その歯に希土類永久磁石 が貼付けられており，またそれ以外の面はなるべく磁 束の漏えいを少なくするため深く削り取られている. 
もう一方の雬車は円板状で，円周上に等間隔で長方形 の希土類永久磁石が貼付けてある。それぞれの歯は同 じモジュールで配置されているが，磁極は逆にしてあ る.したがって二つの歯が小さなギャプで取付けられ ているとし，一つの雬車が回転したとき，吸引力によ りそのトルクは他方へ伝達される。このとき, 電磁石 のコイルへ電流が印加されると, それにより磁束が変 化し, 吸引力すなわちトルクが変化する.このトルク が振䖝制御のための操作力となる。

磁気歯車系の座標系を図 1 に示す. 図中 $a_{1}$ は電磁石 の穴半径, $a_{2}$ は電磁石の菌の部分の内半径, $a_{3}$ は外半 径, $a_{4}$ はコイルの外半径, $a_{5}$ は従動側の円板形歯車の 歯の部分の平均半径, $Z$ は原動側歯車の永久磁石表面 より測られた軸方向の座標, $Z_{1}, Z_{2}$ は永久磁石と電磁 石の接着面の座標および電磁石鉄しんの山部の軸方向 座標であり，hは永久磁石の厚みである.

永久磁石と電磁石の結合系の磁界解析は長屋ら により与えられている，すなわちコイルを有する円筒 形の鉄しんに厚み方向に磁化された円筒形永久磁石が 結合された場合の空間上の一点における磁束密度は

$$
B^{\prime}=B_{e c}(r, z, I)+B_{p_{z}}(r, z)
$$
ここに

$$
\left.\begin{array}{l}
B_{e c}(r, z, I)=J_{c e}(I) F_{c e}(r, z) \\
B_{p z}(r, z)=J_{c p} F_{c e}(r, z)
\end{array}\right\}
$$

式（1）の右辺第 1 項は電磁石の影警を表し, 第 2 項は 永久磁石による鉄しんの磁化の影解を表す。またJce はコイルによる鉄しんの磁化の強さを，Jcp は永久磁 石による鉄しんの磁化の強さを表す，一方，本報の場 合, 図 1 に示すように鉄しん部分は霜車の雪の部分を 除いて削り取られているため, $J_{c p}, F_{c e}(r, z)$ などは文 献( 3 )の式をそのまま用いることはできない.そこで 削り取られた部分の影望を考虑し， $J_{c e}, J_{c p}, F_{c e}$ を誘導 すると, 次式が得られる。

$$
\left.\begin{array}{l}
J_{c e}(I)=B_{0}(I) / n \\
J_{c p}=(1-\nu) J_{0} G_{p} / G_{c p}
\end{array}\right\}
$$

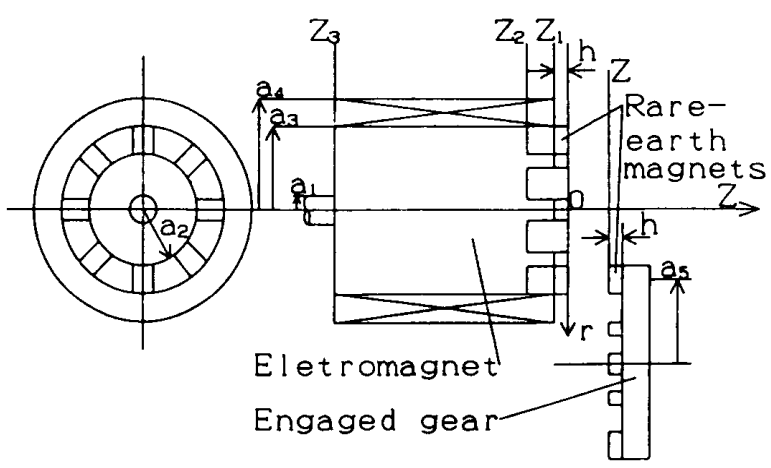

図 1 磁気歯車の座栖系と解析モデル

$$
\begin{aligned}
& F_{c e}(r, z)=\int_{z_{2}}^{z_{1}}\left[f_{z}\left(a_{3}, r, z-\zeta\right)-f_{z}\left(a_{1}, r, z\right.\right. \\
& -\zeta)] d \zeta-\int_{z_{2}}^{z_{1}}\left[f_{z}\left(a_{2}, r, z-\zeta\right)\right. \\
& \left.\quad-f_{z}\left(a_{1}, r, z-\zeta\right)\right] d \zeta-M \int_{z_{2}}^{z_{1}}\left[f_{z}\left(a_{3}, r, z-\zeta\right)\right. \\
& \left.\quad-f_{z}\left(a_{2}, r, z-\zeta\right)\right] d \zeta
\end{aligned}
$$

ここに

$$
\begin{aligned}
& G_{p}=\left[G_{p r}^{2}+G_{p_{z}}^{2}\right]^{1 / 2} \\
& G_{c p}=\left[G_{c p r}^{2}+G_{c p z}^{2}\right]^{1 / 2} \\
& G_{p r}=M\left\{\int _ { a _ { 2 } } ^ { a _ { 3 } } \int _ { - h } ^ { 0 } \left[f_{r}\left(a_{3}, r,-h-\zeta\right)\right.\right. \\
& \left.\left.-f_{r}\left(a_{2}, r,-h-\zeta\right)\right] r d \zeta d r\right\} \\
& G_{p_{z}}=M\left\{\int _ { a _ { 2 } } ^ { a _ { 3 } } \int _ { - h } ^ { 0 } \left[f_{z}\left(a_{3}, r,-h-\zeta\right)\right.\right. \\
& \left.\left.-f_{z}\left(a_{2}, r,-h-\zeta\right)\right] r d \zeta d r\right\} \\
& G_{c p r}=\int_{a_{2}}^{a_{9}} \int_{z_{3}}^{z_{2}}\left[f_{r}\left(a_{3}, r, z_{2}-\zeta\right)\right. \\
& \left.-f_{r}\left(a_{1}, r, z_{2}-\zeta\right)\right] r d \zeta d r \\
& +M\left\{\int _ { a _ { 2 } } ^ { a _ { 2 } } \int _ { z _ { 2 } } ^ { - h } \left[f_{r}\left(a_{3}, r,-h-\zeta\right)\right.\right. \\
& \left.\left.-f_{r}\left(a_{2}, r,-h-\zeta\right)\right] r d \zeta d r\right\} \\
& G_{c p_{2}}=\int_{a_{2}}^{a_{3}} \int_{z_{3}}^{z_{2}}\left[f_{z}\left(a_{3}, r, z_{2}-\zeta\right)\right. \\
& \left.-f_{z}\left(a_{1}, r, z_{2}-\zeta\right)\right] r d \zeta d r \\
& +M\left\{\int _ { a _ { 2 } } ^ { a _ { 3 } } \int _ { z _ { 2 } } ^ { - h } \left[f_{z}\left(a_{3}, r,-h-\zeta\right)\right.\right. \\
& \left.\left.-f_{z}\left(a_{2}, r,-h-\zeta\right)\right] r d \zeta d r\right\} \\
& \begin{array}{l}
f_{z}(d, r, z)=\frac{1}{2 \pi\left[(d+r)^{2}+z^{2}\right]^{1 / 2}} \\
\quad \times\left\{\frac{d^{2}-r^{2}-z^{2}}{(d-r)^{2}+z^{2}} E\left(k^{\prime}\right)+K\left(k^{\prime}\right)\right\}
\end{array} \\
& f_{r}(d, r, z)=\frac{z}{2 \pi r\left[(d+r)^{2}+z^{2}\right]^{1 / 2}} \\
& \times\left\{\frac{d^{2}+r^{2}+z^{2}}{(d-r)^{2}+z^{2}} E\left(k^{\prime}\right)-K\left(k^{\prime}\right)\right\} \\
& E\left(k^{\prime}\right)=\int_{0}^{\pi / 2}\left[1-k^{\prime 2} \sin ^{2} \theta\right]^{1 / 2} d \theta \\
& K\left(k^{\prime}\right)=\int_{0}^{\pi / 2} \frac{d \theta}{\left[1-k^{\prime 2} \sin \theta\right]^{1 / 2}} \\
& k^{\prime 2}=\frac{4 d r}{(d+r)^{2}+z^{2}}
\end{aligned}
$$

上式で $B_{0}(I)$ は電流 $I$ の印加により空しんコイルの 内側に作られる平均磁束密度であり，これらの決定の 仕方については，文献 $(3)$ に示すとおりである。 $n$ は 反磁界係数，レは永久磁石と鉄しんの結合により生ず る磁束漏れの漏れ係数, $J_{0}$ は永久磁石の磁化の強さで ある．前述のように本報では制御雪車の曾の部分以外 
は削り取られているため，削り取られた部分の鉄しん の断面箖と一様な鉄しんの断面穓の比 $M$ を用いて， その影管を式(4)および 5 )に取り入れている。

一方, 長方形永久磁石を歯車の雪とした磁気歯車の 磁束密度および伝達トルクの解析は文献 (5)に与えら れている.その解析では長さ $a$, 幅 $b$, 厚さ $h$ の長方形 磁石を長方形電流に置き換えて解析しており，たとえ ば図 2 の $\mathrm{ABCD}$ を流れる電流により任意の点 $\mathrm{P} に$ 作 られる磁束密度は

$$
B_{P b}(X, Y, Z)=\int_{-h}^{0} B_{P^{\prime}}(X, Y, Z-\zeta) d \zeta
$$

ここに， $X, Y, Z$ は永久磁石素片の中心ょり取られた

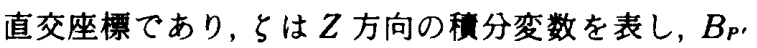
は文献 $(5)$ に示されるとおりである。

永久磁石，コイルおよび鉄しんの作る磁束密度は式 (1) と（7）の足し合わせで表され

$$
B_{P}=B_{P b}(X, Y, Z)+B_{e c}(r, Z, I)+B_{P z}(r, Z)
$$

$2 \cdot 2$ 伝䔔トルクの解析 図1のように一組の永 久磁石が従動歯車中心から半径 $a_{5}$ の距離に置かれた とき, 従動菌車の中心まわりのトルクは

$$
\begin{gathered}
T(Z, I)=\frac{J_{0}}{\mu_{0}} \int_{z}^{z+h} \int_{-b / 2}^{b / 2}\left\{B_{P 2}(Y)\right. \\
\left.-B_{P 1}(Y)\right\}\left(a_{5}+Y\right) d y d \zeta \ldots \ldots .
\end{gathered}
$$

ここに $B_{P 2}$ は図 2 で $\mathrm{AD}$ 線上の磁束密度であり， $B_{P 1}$ は $\mathrm{BC}$ 線上の磁束密度である。式( 9 )に式 ( 8 )を代入 すると, 制御電流に対する伝達トルクが得られる. 式 (9)は一組の磁石の結果であるが, 磁気歯車のように 歯が他の部分でも重なっている場合は, 一組の歯が完 全に重なる場合を $C=1$ とし，それ以上では $C>1$ の ように重なり部分の割合を $C$ とすると歯車全体の伝

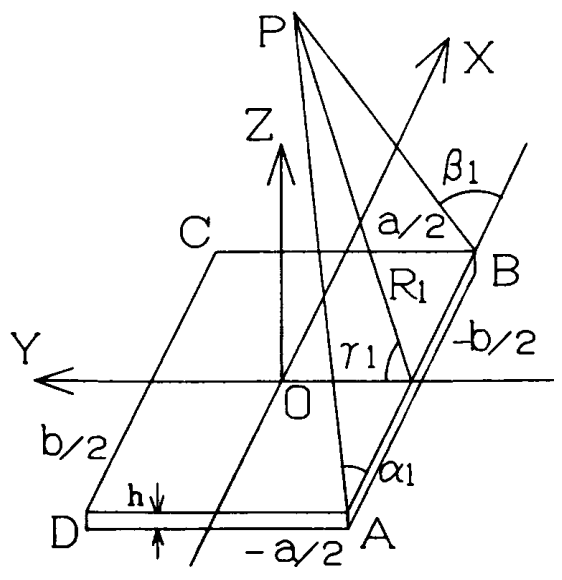

図 2 長方形電流の座標

達トルクは(5)

$$
T_{m}=C T
$$

として計算しても良い。このとき回転ばね定数は二つ の歯車の回転角のずれ（相対回転角）を $\theta$ としたとき

$$
K=T_{m}(Z, I) / \theta
$$

で与えられる．また操作卜ルクは歯車の初期設定の位

置からの振動等による相対回転角を $\theta$ とすると

$$
U(Z, \theta, I)=I_{m}(Z, \theta, I)-\dot{T}_{m}(Z, \theta, 0) \cdots \cdots(12)
$$

で表される。ここに $I$ は制御電流， $Z$ は磁石間浾， $\theta$ は両䨑車の回転角のずれ(相対回転角)を表す. 式(12) の $U$ は上式より磁束密度 $B_{e c}(I)$ のみに以存する量で あるから, 制御電流 $I$ と操作力（トルク） $U$ の関係が 式(12)により決定される。

表 1 は数値計算と実験に用いた本系の諸元である。

\begin{tabular}{|c|c|c|}
\hline $\begin{array}{l}\text { Magnetization strength of } \\
\text { rare-earth magnetic blocks }\end{array}$ & $\mathrm{J}_{\mathrm{o}}$ & $0.84\left(6 \mathrm{~b} / \mathrm{m}^{2}\right)$ \\
\hline Width of magnetic blocks & a & 0.010 (in) \\
\hline Length of magnetic blocks & b & $0.015(\mathrm{~m})$ \\
\hline Thickness of magnetic blocks & $\mathrm{h}$ & $0.003(\mathrm{~m})$ \\
\hline $\begin{array}{l}\text { Radius of hole of the } \\
\text { electromagnet }\end{array}$ & $a_{1}$ & $0.0105(\mathrm{~m})$ \\
\hline $\begin{array}{l}\text { Radius of inner edge of } \\
\text { convexes }\end{array}$ & $a_{2}$ & $0.0135(\mathrm{~m})$ \\
\hline $\begin{array}{l}\text { outer radius of the } \\
\text { electromagnet }\end{array}$ & $a_{3}$ & $0.0285(\mathrm{~m})$ \\
\hline Outer radius of the coil & $a_{4}$ & $0.0385(\mathrm{~m})$ \\
\hline Depth of the convexes & $d$ & $0.020(\mathrm{~m})$ \\
\hline Length of the coil & $\mathrm{L}$ & $0.105(\mathrm{~m})$ \\
\hline $\begin{array}{l}\text { Number of turn of the coil } \\
\text { Mean radius of the }\end{array}$ & $N$ & 1000 \\
\hline driving gear & $r_{1}$ & $0.021(\mathrm{~m})$ \\
\hline $\begin{array}{l}\text { Mean radius of the } \\
\text { engaged gear }\end{array}$ & $\mathrm{r}_{2}$ & $0.063(\mathrm{~m})$ \\
\hline Modulus of magnetic gears & ш & 7 \\
\hline Factor of the convexes & $y$ & 0.45 \\
\hline $\begin{array}{l}\text { Overlapped rate of teeth } \\
\text { Magnetic permeability }\end{array}$ & c & 1.23 \\
\hline in the air & $4 \pi$ & $10^{-7}(\omega \mathrm{b} / \mathrm{ATm})$ \\
\hline
\end{tabular}
ここで鉄しんにはSS-41 材を用いている。計算に必要 な反磁界係数 $n$ は文献 ( 3 ) と同様に $K=L /(2 a)$ と $n$ の関係より決定した。本系の場合，K=1.842であるの で, $n=0.16$ となる.また漏れ係数 様に計算した。本例の場合は $\nu=0.71$ となる。

\section{表 1 数值計算と実䀫の諸元}


前述のように, 伝達トルク $T_{m}$ は磁石間隙 $Z$ と相対 回転角 $\phi$ の関数で与えられるが，その関係を二つの電 流 $(I=0 \mathrm{~A}, I=2 \mathrm{~A})$ について示したものが図 3 およ び図 4 であり，この図の伝達トルクの頃きよりばね定 数が決定される.図 5 より磁石間げき $Z=0.0005 \mathrm{~m}$ と $Z=0.002 \mathrm{~m}$ のときのばね定数と曾車の相対回転角の 関係を最小二乗法により求めると,近似的に次のよう に表される。

$$
\begin{aligned}
& Z=0.0005 \mathrm{~m} \text { のとき } \\
& K=0.00307 \phi^{2}-0.03057 \phi
\end{aligned}
$$

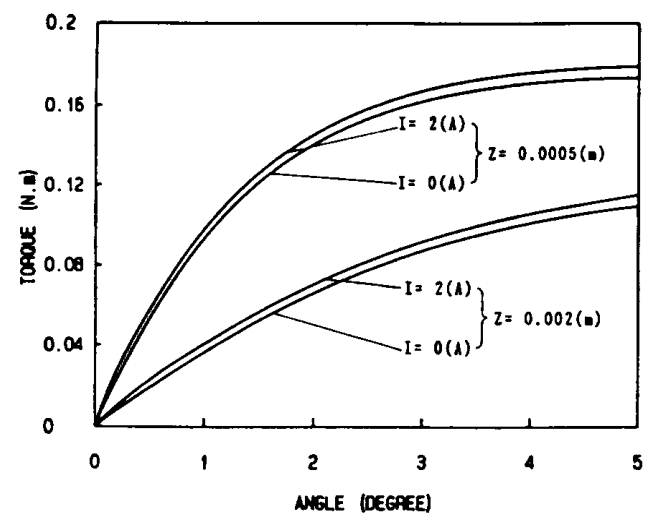

図 3 伀達トルク $T$ と相対回転角 $\phi$ の関保

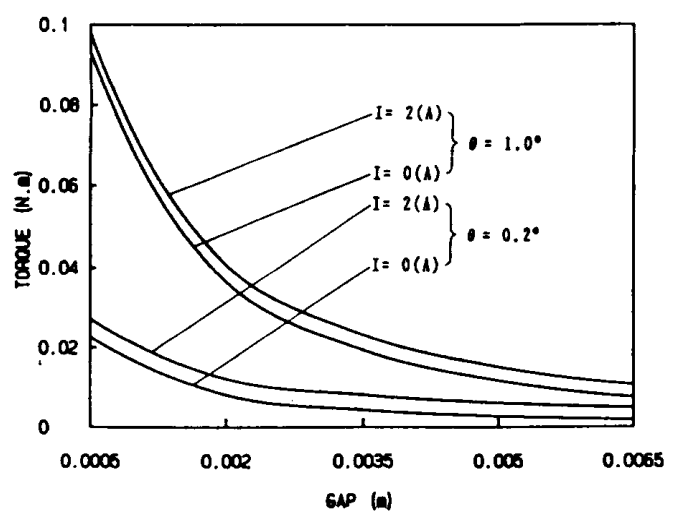

図 4 伝達トルク $T$ と磁石間げき $Z$ の関係

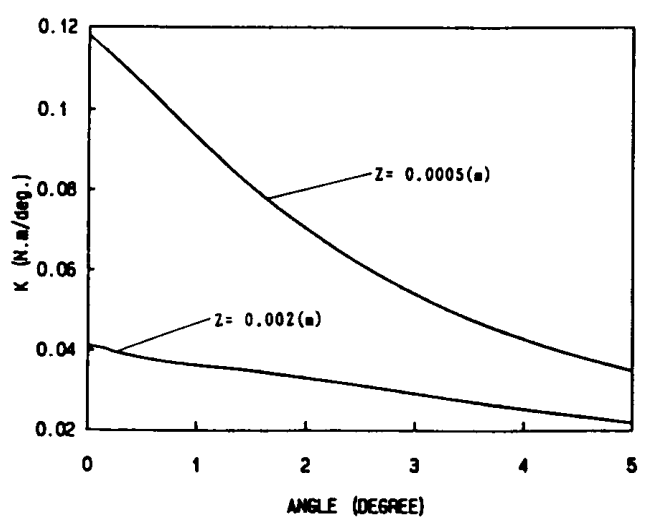

図 5 相対回転角 $\phi$ とばね定数 $K$ の成倸
$+0.12017[\mathrm{~N} \cdot \mathrm{m} / \mathrm{deg}$.

$$
\begin{aligned}
& Z=0.002 \mathrm{~m} \text { のとき } \\
& K=-0.00376 \phi+0.04025[\mathrm{~N} \cdot \mathrm{m} / \mathrm{deg} .]
\end{aligned}
$$

上式より本系の復原力は明らかに磁石間げき $Z$ と相 対回転角 $\phi$ の両方に対し非線形となっていることが わかる。

\section{3. スライティングモード制御}

3.1 磁気贯高伝䢖系の振功モテル 本系の振動 モデルは図6のような 2 自由度系として考えることが できる.両歯車の初期設定位嘈からの回転角を $\theta$ とお くと, 運動方程式は

$$
\left.\begin{array}{l}
J_{1} \ddot{\theta}_{1}+K\left(r_{1} \theta_{1}-r_{2} \theta_{2}\right) / r_{1}=-F r_{1}+N \\
J_{2} \ddot{\theta}_{2}-K\left(r_{1} \theta_{1}-r_{2} \theta_{2}\right) / r_{2}=F r_{2}-f(t)
\end{array}\right\}
$$

ここにドットは時間 $t$ に関する微分を表し， $\theta_{1}$ は原動 䨑車の初期設定位置からの回転角, $\theta_{2}$ は従動雪車の回 転角, $r_{1}\left[=\left(a_{2}+a_{3}\right) / 2\right]$ は原動蒾車のピッチ円半径（磁 石の中心までの半径) であり, $r_{2}\left(=a_{5}\right)$ は従動霜車の ピッチ円半径である。また $J_{1}$ は原動軸と歯車の慣性能 率, $J_{2}$ は従動歯車と軸の慣性能率, $K$ は磁気ばね定 数, $N$ は外部から与えられるトルク, $f$ は系の負荷卜 ルクであり，Fはトルクである.

式(15)を減衰を考虑して書きかえると

$$
\ddot{\theta}+2 \mu \dot{\theta}+\rho^{2} \theta=M_{2} b_{1}-N / J_{1}-f(t) / J_{2}
$$

$こ こ に$

$$
\left.\begin{array}{l}
\theta=\theta_{2}-\theta_{1} r_{1} / r_{2}, M_{2}=F r_{2} \\
M_{2}=M_{1} r_{1} / r_{2}, \rho^{2}=K\left(1 / J_{2}+1 / J_{1}\right) \\
M_{1}=F r_{1}, b_{1}=1 / J_{2}+r_{1}^{2} / r_{2}^{2} J_{1}
\end{array}\right\}
$$

また $2 \mu$ は本系の摩擦および空気隇衰等を考虚した等 価減衰を表す項である。いま

$$
X_{1}=\theta, X_{2}=v=\dot{\theta}
$$

とおいて, 式(16)を状態方程式に書き換えると

$$
\{\dot{X}\}=[A]\{X\}+\{B\} U(t)+\{D(t)\}
$$
ここに

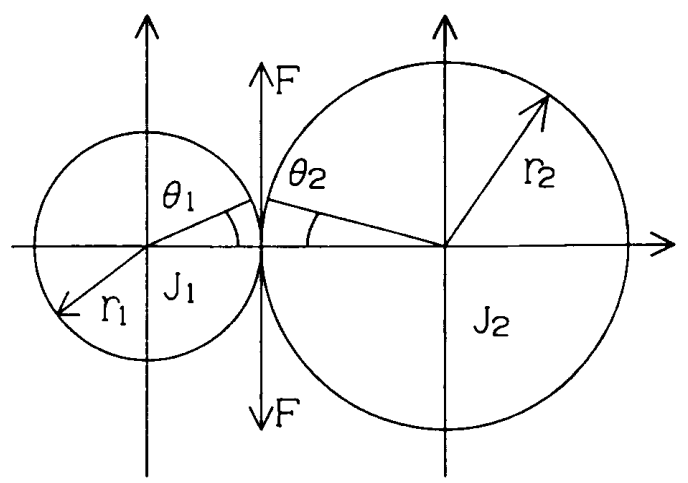

図 6 磁軍系のモデル 


$$
\begin{aligned}
& \{X\}=\left[\begin{array}{l}
X_{1} \\
X_{2}
\end{array}\right],[A]=\left[\begin{array}{cc}
0 & 1 \\
-\rho^{2} & -2 \mu
\end{array}\right] \\
& \{B\}=\left[\begin{array}{l}
0 \\
b_{1}
\end{array}\right],\{D\}=\left[\begin{array}{c}
0 \\
-N / J_{1}-f(t) / J_{2}
\end{array}\right] \\
& U=M_{2}
\end{aligned}
$$

また, $\theta$ は相対回転角, $v$ は速度を表す.式(19)加わ かるように本系は相対変位を用いることにより，1 自 由度系の問題に帰着する。

$3 \cdot 2$ スライディングモードによる制御系の設計 式(19)で外乱がない系のフィードバック制御を考える と

$$
U=-(E)(X)=-\sum_{i=1}^{2} e_{i} x_{i}
$$

ここに $(E)$ は制御べクトルである.スライディンクモ 一ド制御では， $(E)$ の要素 $e_{i}$ は次のように選ばれる。

$$
e_{i}=\left\{\begin{array}{ll}
f_{i} & x_{i} \sigma(x)>0 \\
g_{i} & x_{i} \sigma(x)<0
\end{array} \quad i=1,2\right.
$$

ここに $f_{i}, g_{i}$ はスライディングモード制御における可 変ゲインである。 また $\sigma(x)=0$ は滑り面であり，切換 之関数 $\sigma$ は

$$
\sigma(x)=(P)\{X\}=\sum_{i=1}^{2} p_{i} x_{i}
$$

式中 $(P)$ は切換えベクトルで制御系の設計時に選定 される、スライディングモード制御では、ベクトル (E)の要素は $\sigma(x) x_{i}$ の量に応じて状態空間内で切換 えられる。いま

$$
V=\sigma^{2}(x) / 2
$$

をリアプノフ関数として選ぶと, 系が渐近安定な条件 は

$$
V=\sigma(x) \dot{\sigma}(x)<0
$$

式(24)を满足する限りスライディングモードが存在す る. 式(22)ょり

$$
\dot{\sigma}(x)=(P)\{\dot{X}\}=(P)([A]-\{B\}(E))\{X\}
$$

となり, $\{Z\}=(P)[A][(P)\{B\}]^{-1}$ とおくと, 滑り状態 の存在条件は

$$
e_{i}=\left\{\begin{array}{ll}
f_{i}>z_{i} & x_{i} \sigma(x)>0 \\
g_{i}<z_{i} & x_{i} \sigma(x)<0
\end{array} \quad i=1,2\right.
$$

滑り状態では， $\sigma(x)=\dot{\sigma}(x)=0$ を満足するので,

$$
(P)[A]\{X\}+(P)\{B\} U=0
$$

系の動的応答を決定する方程式は，次式で与えられる 操作力を用いて求められる。すなわち

$$
U_{\mathrm{eq}}=-[(P)\{B\}]^{-1}(P)[A](X\}
$$

を状態方程式に代入することにより次式のように求め られる.

$$
\begin{aligned}
& \{\dot{X}\}=\left([I]-\{B\}[(P)\{B\}]^{-1}(P)\right)[A]\{X\} \\
& (P)\{X\}=0
\end{aligned}
$$

ここに[I]は単位マトリックスを表す。式(29)におい て固有值の実数部が負すなわち極が左半面にあれば系 は安定である，すなわち通常の極配置の方法により安 定な系を設計することができる。

系に外乱が作用する場合は操作力に外乱に対する入 力項を追加すれば良い。すなわち

$$
U=-(E)\{X\}-W \operatorname{sgn}(\sigma)
$$

ここに

$W \geqq\left|H_{\max }\right| / b_{1}$

であり， $H_{\max }$ は外乱の最大振幅である. 式(30)の制御 入力はもちろん滑り状態の存在条件 $\sigma \cdot \dot{\sigma}<0$ を满足 している.

\section{4. 数僆シミュレーションおよび实験}

数值計算および実験に用いた慣性能率は， $J_{1}=$ $23.334 \times 10^{-3} \mathrm{~kg} \cdot \mathrm{m}^{2}, J_{2}=64.494 \times 10^{-4} \mathrm{~kg} \cdot \mathrm{m}^{2}$ でる。 また隇衰項 $\mu$ は無制御状態の振動応答より決定した， その值は $\mu=0.76 \mathrm{~s}^{-1}$ である. 本柬車で磁石間距離を $Z=0.0005 \mathrm{~m}$ および $Z=0.002 \mathrm{~m}$ とし, 角度 $\phi$ を $0.1^{\circ}$ から $3^{\circ}$ まで変化させたときの磁気ばね定数の最大值 と最小值は式(13)および式(14)より次のように求めら れる.

$$
\left.\begin{array}{l}
K_{\max }=0.11171 \mathrm{~N} \cdot \mathrm{m} / \mathrm{deg} . \\
K_{\min }=0.00290 \mathrm{~N} \cdot \mathrm{m} / \mathrm{deg} .
\end{array}\right\}
$$

スライディングモードの超平面の要素は極配置法より $C_{1}=5, C_{2}=1$ と決定した。このとき式(31)のようなば ね定数の変化に対するフィードバックベクトルは次の ように求められる。

$$
\left\{\begin{array} { l } 
{ f _ { 1 } = 3 0 } \\
{ g _ { 1 } = - 3 0 , }
\end{array} \quad \left\{\begin{array}{l}
f_{2}=5 \\
g_{2}=-5
\end{array}\right.\right.
$$

また，Wの值を 2 にとり，これらの值を状態方程式 に代入すると，固有值はすへてて左半平面にあることが わかる．図 7 に本システムの実験装置の概要を示す。

1 D.C motor

2 Electromagnet

3 Engaged gear

4 Tachogenerator

$5 \mathrm{~A} / \mathrm{D}$ board

6 Microcomputer

7 D / A board

8 Function generator

9 Power amp.

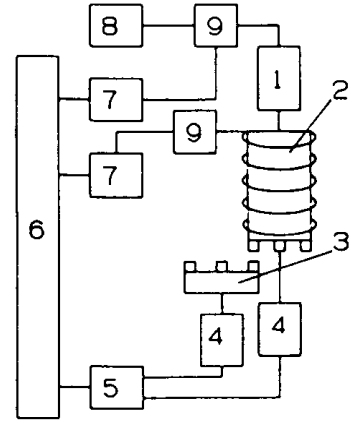


図でマイクロコンピュータ6による駆動信号は D/A コンバータボード 7 を通してパワーアンプ 9 および直 流モータ1に入力され，ドライブ側の磁気菌車を回転 させる.このとき, 磁気歯車の伝達トルクにより従動 側の歯車 3 にももちろん回転が伝えられる．原動側と 従䵢側の振動速度はそれぞれの畨車に取付けられた速 度発電機の信号を A/D コンバータボードを通してマ イクロコンピュータに入力し，その差を計算すること で求められ，またその信号を積分することで相対振動 変位が計算される。制御信号はマイクロコンピュータ により作られ、それをD/A コンバータボードおよび パワーアンプ 9 を通して電磁石のコイルに印加する。 この信号により原動側歯車の磁束密度が変化し，振動 を除去する．このときのサンプリングタイムは $2 \mathrm{~ms}$ である.また，調和起振力を与えるときは，関数発生器 8 より正弦信号を発生し, パワーアンプに入力する.

まず，はじめにレギュレー夕問題を考える。図 8 は

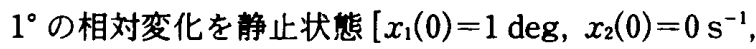

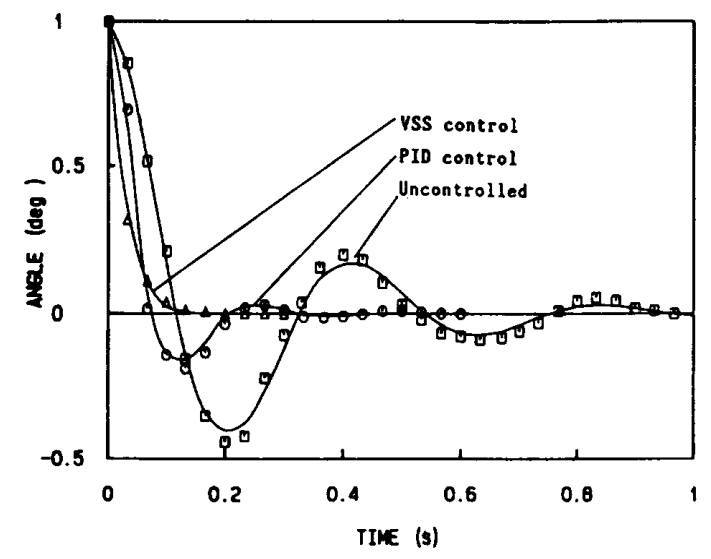

図 8 相対変位 $\theta$ の振動波形 $\left(K=K_{\mathrm{m} \mid \mathrm{n}}\right.$, —：計算值, $\bigcirc, \square, \Delta:$ 実験值)

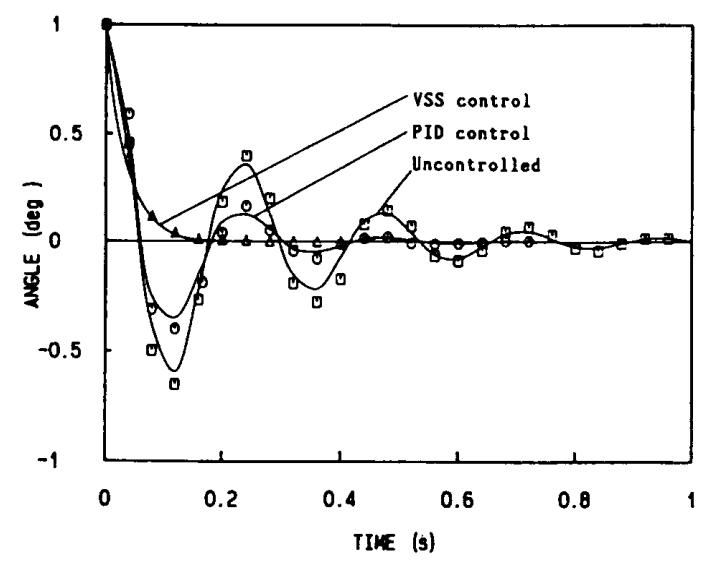

図 9 相対変位 $\theta$ の振䵢波形 $\left(K=K_{\max }\right.$, 一一 : 計算值, $\bigcirc, \square, \Delta$ : 実験值)
$\left.K=K_{\mathrm{m} n}\right]$ で与え，急に放したときの振助波形である。 図中実線は計算值，白丸印，四角印，三角印などの記 号は実験値である，比较のために代表的な線形制御 (PID) および無制御の結果も求め図示した，図より本 報の VSS 制御ではオーバシュートもなく速やかに整 定するのに対し，PID制御ではオーバシュートがあり 整定時間も長くなっており，VSS制御が有利なこと がわかる．図 9 は本制御法のロバスト性を検討したも ので, 磁気ばね定数は $K_{\min }$ から $K_{\max }$ へ変わってい る.図 8 の曲線と比較するとVSSを用いた場合はほ とんど変化がないのに示し，線形な PID制御では相 当変化が見られる.このことは本報のスライディング モード制御は本系のように非常に非線形性の強い系で も十分なロバスト性があり，有利な方法であることを 示している.また, 理論値と実験值は図 8 , 図 9 ともに 良く一致しており，本解析が正しいことを裹付けてい る.

一方, 図7でモータ 1 に関数発生器 8 から定常振動

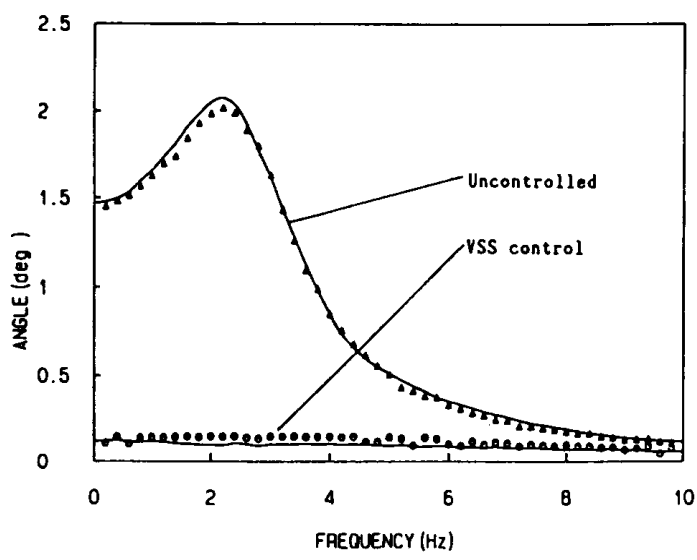

図 10 相対変位 $\theta$ の応答曲線 $\left(K=K_{\min }\right.$, 一：計算值, $\mathrm{O}, \Delta$ : 実験値)

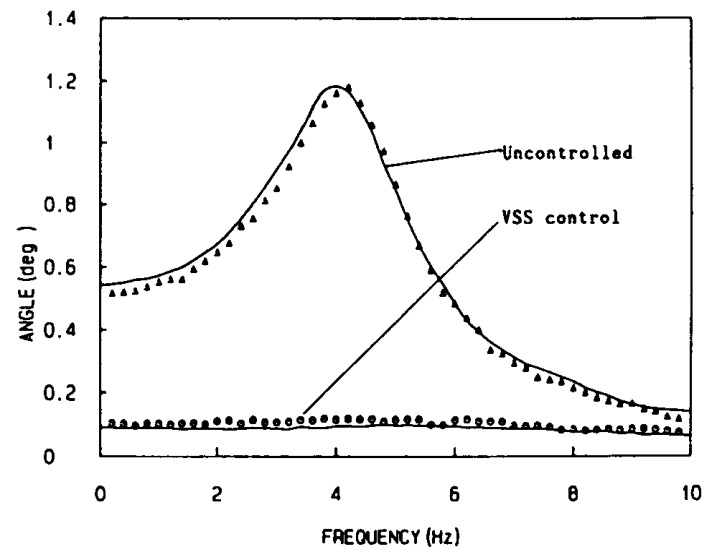

図 11 相対変位 $\theta$ の応答曲線 $\left(K=K_{\max }\right.$, 一一：計算值, ○. $\Delta$ : 実験值) 
信号を与え，歯車系に定常ねじり振助を起こさせた結 果を図 10 に示す.図において䋖軸は相対ねじり角の振 動振幅を表し，横㨁は加振周波数を表す。ここでばね 定数は $K=K_{\min }$ としてある. 図から無制御では明らか に共振が生じ相当大きな振幅となるのに対し, スライ ディングモード制御による応答曲線は共振もなく, 全 周波数領域にわたって振幅も非常に小さく抑制される ことがわかる．また，図 11 はばね定数を $K=K_{\max } に$ 変化させた場合の周波数応答曲線である。この場合も 図 10 に対し，ばね定数が約 4 倍にも変化しているに もかかからず, スライディングモード制御による結果 は図 10 の場合とほとんど同じである.すなわち非線形 な系に対するロバスト性が保障されることがわかる。 またこの場合も実験值と理論值は非常に良く一致して いる.

\section{6. 桔}

本報は長方形永久磁石の小片を同一円周上に歯車の 菌のように配置し，モジュールの同じ歯を持つ他の円 板と組合せ，磁石間の吸引力により伝達する磁気雪車 機粠を提案した。しかし本系では，磁石間吸引力が小 さいために振動が発生しやすいため,その振動を吸収 するため,コイルを巻いた円柱状の鉄しん上に菌車の 宷を接着した磁束制御による除振機構を提案した。こ の場合永久磁石の吸引力は単に菌車のトルクの伝達の ためにのみ用いられ，振動制御のための操作力は電磁 石により与えられる。その内容を要約すると

（1）本磁気齒車機樓の伝達トルク，磁気ばね定数， 操作力と制御電流との関係を与える理論式を誘導し た.

（2） スライディングモード制御による設計法を提 案し，それに基づく系の応答式を誘票した。

（3）本制御法の妥当性を検証するため, 実験をも
行い, 上記の理論値と比較したところ両者は非常に良 く一致した。

（4）本報のスライディングモード制御と通常の線 形制御 (PID) との比較を行ったところ，スライディン グモード制御は本系のような強い非線形性を持った系 にも十分にロバスト性があり，PID制御よりも優れて いることがわかった。

\section{文献}

(1) Metcalfe, A. V. and Burdess, J. S., Experimental Evalu ation of Wide Band Active Vibration Controllers, Trans. ASME, J. Vib. Acous., 112(1990), 535-541.

(2) Su, H., Rakheja, S. and Sankar, T. S., Vibration Isola tion Characteristics of an Active Electromagnetic Force Generator and the Influence of Generator Dynamics, 文献 ( 1 )の 8-15 ベージ.

(3) Nagaya, K. and Arai, N., Analysis of a Permanent Magnet Levitation Actuator with Electromagnetic Control, Trans. ASME, J. Dyn. Syst. Meas. Control, 113 (1991), 472-478.

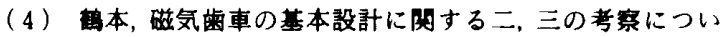
て, 第 1 回电磁力蔺連のタイナミックス請演論文集, (1989-6), 375-378.

（5）長屋・ほか 4 名，無接触吸引型磁気蒾車の伝逶トルクおよ び振動解析, 第 3 回磁力関連のタイナミックス誰演論 文集，(1991-6)，116-121.

(6) Utkin, V.I., Variable Structure System with Sliding Modes, IEEE Trans. Aut. Contr., AC-22-2(1977), 212222.

(7) White, B. A., Range-Space Dynamics of Scalar Variable Structure Control System, IEEE Proc. D, 133-1 (1986), 35-41.

(8) Slotine, J. J. and Coetsee, J. A., Adaptive Sliding Controller Synthesis for Non-Linear System. Int. J. Contr., 34-6(1986), 1631-1651.

(9) Tian, H.Q. and Liao, X. G., Computer Aided Design of Multivariable Variable Structure Control System by Geometric Method, 4th Int. Conf. on Computer-Aided Prod. Eng., (1988), 375-379, Edinburgh, U. K.

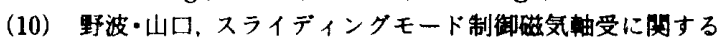
研究, 機論, 58-545, C(1992), 106-111.

（11）岩田・内田，除振システムのリレー法式によるVSS 制御, 機諞, 57-534, C(1991), 40-44. 